DOI https://doi.org/10.32837/app.v0i66.715

УДК 327.019.51:32-027.22(477)

\author{
К. В. Савон \\ orcid.org/0000-0001-5624-7262 \\ аспірантка кафедри політичних теорій \\ Національного університету «Одеська юридична академія»
}

\title{
ВПЛИВ ПОЛІТИКИ «М'ЯКОЇ СИЛИ» НА ІМІДЖ ДЕРЖАВИ
}

Вступ. У стратегії розвитку держави своє відображення знаходять категорії «сила», «жорстка сила» та «м' яка сила». 3 появою неолібералізму у світі постали нові виклики щодо реалізації стратегічних напрямів внутрішньої та зовнішньої політики, які потребують подальшого дослідження змісту та виявів цих категорій. Одним із таких викликів стала залежність від впливу інших держав у політичній, економічній і соціальній сферах.

Вчені по-різному інтерпретували категорію «сили» в дослідженні політики. Т. Гоббс трактував «силу» через досягнення вигоди у майбутньому. Г. Моргентау розглядав категорію «сили» через «владу». Г. Кіссинджер ототожнював категорії «сили» та «впливу». Ч. Фрімен дав визначення «сили» як здібності управляти рішеннями та діями інших. Е. Карр - британський учений, який займався дослідженням міжнародних відносин, визначив категорію «сили» через використання матеріальних ресурсів з метою примусити інших робити те, чого раніше вони робити не хотіли. Схоже з Карром визначення дав американський політолог Дж. Стоссінджер: сила у сфері міжнародних відносин - це сукупність матеріальних і нематеріальних ресурсів, застосовуваних з метою впливу на поведінку інших держав (Гукасов, 2011). Таким чином, категорію «сили» можна визначати через примус, підкуп, вплив, симпатію. На мою думку, Г. Моргентау найточніше описав категорію «сили» через поняття «влади». Адже влада і є кінцевим результатом використання сили.

Виклад основного матеріалу. Американський вчений Дж. Най запропонував терміни «м'яка сила» та «жорстка сила». Однак розмежування на «жорстку» та «м'яку» сили були розроблені на основі формули Р. Клайна, яка відображає оцінювання сукупності державної сили: $\mathrm{P}=(\mathrm{C}+\mathrm{E}+\mathrm{M}) \times(\mathrm{S}+\mathrm{W})$, де $\mathrm{P}$ - сила держави $=(\mathrm{C}$ - населення і територія + E - економічний складник + M - військовий складник) х (S - стратегія + W - воля до здійснення державної стратегії). У цій формулі перша частина відображає об'єктивний (матеріальний) складник, а друга - суб'єктивний (духовний). За допомогою цієї основи Дж. Най позначив матеріальні елементи як «жорстку силу», а духовні елементи - як «м' яку силу» (Семченко, 2014).

«Жорстка сила» означає вплив на інших за допомогою примусу, залякування та використання нарощування військової та економічної могутності, тоді як інструментами «м'якої сили» є публічна дипломатія, ідеологія та культура.

Ефективність застосування «м' якої» та «жорсткої» сили змінювалися в різні періоди історії. В сучасну епоху інформаційного суспільства «м' яка сила» за допомогою позитивного іміджу держави може впливати на інших, підвищуючи авторитет держави на міжнародній арені. Однак приклад України та інших держав показує важливість нарощування і «жорсткої сили». Д. Дрезнер вважає, що «м' яка сила» ефективна лише за умови, що держава може в будь-який момент застосувати «жорстку силу» (Фесик, 2012; Филимонов, 2012, с. 33).

Глобалізаційні процеси та науково-технічний розвиток призвели до потреби презентації своєї країни у зовнішньому світі та отримання позитивної оцінки іншими. Позитивний імідж держави залежить саме від використання «м'якої сили», тому необхідно більш детально проаналізувати, що включає ця категорія. За основу засобів застосування «м'якої сили» було взято дослідження вченого Ін Фань. Він включив 5 інструментів для просування «м'якої сили»:

- здатність формувати чужий вибір;

- приваблювати, а привабливість часто призводить до поступливості;

- примушувати інших хотіти того ж результату в силу культурної чи ідеологічної привабливості; 
- досягнення країною цілей у світовій політиці на основі захоплення иї цінностями, беручи з неї приклад, прагнучи до рівня ії розвитку;

- ключовий елемент - лідерство, яке і змушує інші країни прагнути того ж (Фесик, 2012; Fan, 2006, p. 11).

The Digital Diplomacy Hub by Portland Communications спільно з Facebook розробили щорічний «Індекс м'якої сили», куди входять 30 країн-лідерів. За основу порівняння держав взяли джерела «м'якої сили» за Дж. Наєм, які включають політичні цінності, культуру та зовнішню політику. Для білыш точних результатів були винайдені 75 показників і проведені соціологічні опитування. О. Русакова більш детально розкрила ці показники: популяризація національної мови як мови міжнародної спільноти; експорт медіа-продукції; проведення Олімпійських ігор; приналежність харизматичних лідерів, які входять у 100 найвпливовіших людей світу; екологічна ситуація в державі; рівень свободи, корупції та насилля; існування впливових бізнес-компаній, які входять у журнал “Fortune"; світовий рейтинг університетів та вільне володіння англійською мовою. У 2019 році до країн-лідерів увійшли Франція, Англія, Німеччина, Швеція, США, Швейцарія, Канада, Японія, Австралія та Нідерланди (Ефанова, 2018, с. 423; Русакова, 2013, с. 52; Portland, 2019).

Кожна країна може мати специфіку вияву і застосування «м'якої сили». Так, вирішальним у просуванні «м'якої сили» Франції є підтримання та висвітлення своєї історичної спадщини, захист і повага до французької мови та кіно. Імідж Франції побудований на основі ії історії, моди, культури, ніж на тому, що відбувається нині. Але є і багато спільного. «М'яка сила» однієї держави впливає на інші країни через привабливість культури, цінностей, мови, релігії, публічної дипломатії та ідеології. В результаті «світ описується як сукупність країн, як сукупність міфічних образів, які витворилися протягом століть більше завдяки митцям, аніж політикам» (Sorman, 2017).

Закордонні та вітчизняні вчені Дж. Бжезинський, А. Гукасов, М. Капітоненко вважають, що саме через «масову культуру» відбувається найбільший вплив «м'якої сили». Масова (популярна) культура повинна мати розважальний характер, бути доступною та задовольняти потреби більшості суспільства. Інструментами просування масової культури є телебачення, соціальні мережі. Саме через них суспільство отримує інформацію щодо держав-лідерів і держав-аутсайдерів (Литовченко, Іванова, 2014).

Світові міграційні процеси призводять до ідентичного запиту в різних країнах, які виражаються, наприклад, у популярності турецьких серіалів в Україні, користуванні Facebook в усьому світі, моді на споживання та розважальний характер буття. Демократія, рівність і повага до інших, терпимість, ринкова економіка, участь у міжнародних організаціях, благодійність, англійська мова, поп-музика, голлівудські фільми, фаст-фуд - все це приклади використання «м'якої сили», які впливають на різні етноси з метою популяризації та просування своїх інтересів у світі.

Значний культурний вплив на інші держави мають США. Дж. Бжезинський стверджуав, що в усьому світі відчувається привабливість американської масової культури. Він вважав, що культурна перевага є недоцціненим аспектом американської глобальної могутності і саме молодь є цільовою аудиторією американської масової культури (Гукасов, 2011).

Великий вплив на просування своєї культури та ідеології Інститути Сервантеса, Британська рада, Гете-інститути тощо. За допомогою цих інститутів влаштовуються культурно-освітні обміни, які ще більше закріплюють позитивний імідж держави-організатора, просуваючи національну мову та культуру.

Релігія також є силою, за допомогою якої можна впливати на політичний процес і зміцнювати свій міжнародний авторитет. Прикладом можна вважати Ватикан, який завжди мав і має величезний вплив на весь світ. Папство часто дає свої коментарі щодо політичних, культурних і соціальних світових проблем, чим і здійснює свою «м'яку силу», орієнтуючись на сучасні суспільні запити.

Саме за допомогою «м'якої сили» князівство Монако отримало своє особливе економічне становище та незалежність від інших держав. Особлива «розкіш» і стиль життя формують імідж держави, який є привабливим для інших. 
Азіатські держави активно займаються просуванням своєї «м' якої сили», детальну увагу зосереджують на цьому КНР та Японія. Китай активно використовує нарощування і «жорсткої сили», проте за допомогою економічних благ таких як доступні та базові речі стає важливим актором на міжнародній арені в економічному секторі. Політика невтручання у справи інших, слідування правилам ринкової економіки західної аудиторії та одна з найбільших діаспор у світі стають ключовими засобами укріплення позитивного іміджу Китаю. Окремим складником є Інститути Конфуція, основним завданням яких є викладання мови. Саме учення Конфуція заклали витоки поняття «м'яка сила».

У 2002 році Японія затвердила стратегію розвитку Cool Japan («Крута Японія»). За допомогою поп-культури, економіки та престижності бренду "made in Japan", манги (художніх коміксів), дипломатії та анімації (частка Японії у виробництві світової анімаційної продукції становить понад 65\%) Японія стала країною з позитивним іміджем (Русакова, 2013, с. 56). Для видатних аніматорів світу було започатковано Японську премію Манга (Japan Mango Aword) (Ефанова, 2018, с. 422).

Окремої уваги заслуговують масштабні наукові, культурні та спортивні заходи, які об'єднують глядачів з усього світу, підіймаючи престиж держави, яка їх проводить. Скандинавські держави застосовують «м'яку силу» через соціальну політику, Нобелівську премію світу, активну боротьбу за екологію, статус «щасливих країн» у різних міжнародних рейтингах. Усі ці заходи викликають повагу та бажання інших країн бути схожими на них.

«М'яка сила» також виражається в участі у міжнародних організаціях та їх фінансуванні. Так, просуванням України займаються міжнародні неурядові організації та фонди. Серед них Всесвітній конгрес українців - суспільна неурядова організація українців, які проживають на території України та за їі межами. Ця організація функціонує більше ніж у 60 країнах світу та допомагає підвищувати авторитет України у світі (Ukrainian World Congress).

Фонд «Відкрий Україну» А. Яценюка функціонує з 2007 року. Фонд створений для покращення позицій України на міжнародній арені та зміцнення публічної дипломатії. Фонд включає такі програми: Молоді лідери, Міжнародний діалог, Культурні горизонти (Open Ukraine). Світова Федерація Українських Жіночих Організацій (далі - СФУЖО) функціонує на 4 континентах у 17 країнах світу та включає 27 організацій. СФУЖО ставить перед собою мету відстоювання гідності та прав українок у світі (WFUWO). Цей перелік стосовно впливів «м'якої сили» можна продовжити, що свідчить про різноманітність їі виявів і широту можливостей.

Висновки. «М'яка сила» $є$ неодмінним пріоритетом діяльності сучасних держав. Імідж держави визначає ії місце у міжнародному просторі та успіх в досягненні своїх цілей. Теоретики та політичні діячі різних держав світу зосереджують свою увагу на використанні «м'якої сили», доповнюючи категорії «м'яка» та «жорстка» сила «розумною», яка поєднує обидві. Нарощування військової сили залякує світове співтоваривство, не викликаючи симпатію до держави. Тому сучасний світ постав перед новими викликами, які потребують розв' язання мирними шляхами, акцентуючи увагу на «м'якій силі» за допомогою створення позитивного іміджу.

Іміджем можна керувати, зосереджуючись на історичному минулому, прикладом чого є Франція, а можна створювати на прикладі Німеччини та Японії імідж, який заснований на сучасних здобутках - якісних товарах і високому рівні життя людей. Україна - держава, яка своїми демократичними настроями, боротьбою за незалежність та мову, революційними змінами, перемогою у багатьох спортивних і культурних змаганнях, великою діаспорою має всі шанси стати державою з привабливим іміджем для відвідування, вкладання коштів, завдяки чому зміцнить свої позиції у світі.

\footnotetext{
Лimepamypa

Гукасов А.В. «Жесткая» и «мягкая» сила как инструменты внешней политики США. Вестник института стратегических исследований ПГЛУ, вип. 1, с. 15-17. 2011. URL: http://old.pglu.ru/science/researches/ nii-panin/vestnik/v1/Gusakov_A_V.pdf.

Ефанова Е.В. Инструменты «мягкой силы» во внешней политике государства. Вестник РУДН. Серия: Политология. 2018. Т. 20. № 3. С. 417-426. URL: https://www.researchgate.net/publication/328820578_ THE_USE_OF_SOFT_POWER_TOOLS_IN_FOREIGN_POLICY.
} 
Русакова О.Ф. Soft power как стратегический ресурс и инструмент формирования государственного бренда: опыт стран Азии. Известия Уральского федерального университета. Серия 3. Общественные науки. 2013, № 3(118). С. 52.

Іванова Ю.С., Литовченко І.В. Трансформація масової культури в умовах інформатизації. Грані № 5 (109), травень 2014 року. С. 80-84.

Семченко О.А. Іміджева політика України : монографія. Київ : Академія, 2014. URL: https://pidru4niki.com/70814/politologiya/imidzheva_politika_ukrayini.

Фесик О. Категорія «м'яка сила» у дослідженнях міжнародних відносин. Науковий вісник Одеського національного економічного університету, 2015. № 11. C. 196-209. URL: http://nbuv.gov.ua/UJRN/Nv_2015_11_20.

Филимонов Г.Ю. Культурно-информационные механизмы внешней политики США. Истоки и новая реальность : монографія. М. : РУДН, 2012. С. 33.

Фесик О. Категорія «м'яка сила» у дослідженнях міжнародних відносин. Науковий вісник Одеського національного економічного університету, 2015. № 11. C. 196-209. URL: http://nbuv.gov.ua/ UJRN/Nv_2015_11_20.

Fan Y. Branding the nation: towards a better understanding. London : Brunel Business School, 2006. 11 p.

Русакова О.Ф. Soft power как стратегический ресурс и инструмент формирования государственного бренда: опыт стран Азии. Известия Уральского федерального университета. Серия 3. Общественные науки. 2013, № 3(118). С. 56.

Світовий Конгрес Українців. Суспільна організація. URL: https:/ /www.ukrainianworldcongress.org/.

Світова Федерація Українських Жіночих Організацій. Міжнародна організація. URL: http:/ / wfuwo.org/. Open Ukraine Arseniy Yatsenyuk Foundation. Благодійний фонд. URL: https:/ /openukraine.org/en.

Sorman Guy El poder blando ABC, зреферувала Галина Грабовська, 2017. URL: https://zbruc.eu/ node/69324.

The soft power 30 by Portland USC Center on Public Diplomacy, 2019. URL: https:/ / softpower30.com/.

\section{References}

Gukasov A.V. (2011) "Zhestkaya" i "myagkaya" sila kak instrumenty vneshney politiki SShA ["Hard" and "soft" power as instruments of US foreign policy]. Vestnik instituta strategicheskikh issledovaniy PGLU, vol. 1, p. 15-17. Retrieved from: http://old.pglu.ru/science/researches/nii-panin/vestnik/v1/Gusakov_A_V.pdf (accessed 19 October 2020) [in Russian].

Efanova E.V. (2018) Instrumenty "myagkoy sily" vo vneshney politike gosudarstva [The use of "soft power" tools in foreign policy]. Vestnik RUDN. Seriya: Politologiya. T. 20. № 3, p. 417-426. Retrieved from: https:// www.researchgate.net/publication/328820578_THE_USE_OF_SOFT_POWER_TOOLS_IN_FOREIGN_ POLICY (accessed 16 October 2020).

Rusakova O.F. (2013) Soft power kak strategicheskiy resurs i instrument formirovaniya gosudarstvennogo brenda: opyt stran Aziiyu [Soft power as Strategic Resource and Tool for Developing the National Brand: the Case of Asian Countries]. Izvestiya Ural'skogo federal'nogo universiteta. Seriya 3. Obshchestvennye nauki. № 3(118). C. 52 [in Russian]. Ivanova Ju.S., Lytovchenko I.V. (2014) Transformacija masovoji kuljtury v umovakh informatyzaciji [The transformation of popular culture in information conditions] Ghrani № 5(109) travenj, p. 80-84 [in Ukrainian]. Semchenko O.A. (2014) Imidzheva polityka Ukrajiny [Image policy of Ukraine] : monoghrafija. Kyjiv : Akademija. Retrieved from: ttps://pidru4niki.com/70814/politologiya/imidzheva_politika_ukrayini [in Ukrainian].

Fesyk O. (2015) Kateghorija "m'jaka syla" u doslidzhennjakh mizhnarodnykh vidnosyn [The evolution of the category "soft power" in international relations research]. Naukovyj visnyk Odesjkogho nacionaljnogho ekonomichnogho universytetu. № 11, p. 196-209. Retrieved from: http://nbuv.gov.ua/UJRN/Nv_2015_11_20 (accessed 18 October 2020).

Filimonov G.Yu. (2012) Kul'turno-informatsionnye mekhanizmy vneshney politiki SShA [Cultural and information mechanisms of U.S. foreign policy]. Istoki i novaya real'nost' : monografiya. M. : RUDN, s. 33 [in Ukrainian].

Fesyk O. (2015) Kateghorija "m'jaka syla" u doslidzhennjakh mizhnarodnykh vidnosyn [The evolution of the category "soft power" in international relations research]. Naukovyj visnyk Odesjkogho nacionaljnogho ekonomichnogho universytetu. № 11, p. 196-209. Retrieved from: http://nbuv.gov.ua/UJRN/Nv_2015_11_20 (accessed 20 October 2020).

Fan Y. (2006) Branding the nation: towards a better understanding. London : Brunel Business School. 11 p. [in Ukrainian].

Rusakova O.F. (2013) Soft power kak strategicheskiy resurs i instrument formirovaniya gosudarstvennogo brenda: opyt stran Aziiyu [Soft power as Strategic Resource and Tool for Developing the National Brand: 
the Case of Asian Countries]. Izvestiya Ural'skogo federal'nogo uni-versiteta. Seriya 3. Obshchestvennye nauki, № 3(118). C. 56 [in Russian].

Svitovyj Kongres Ukrajinciv. Suspiljna orghanizacija. Retrieved from: https://www.ukrainianworldcongress. org/ (accessed 20 October 2020) [in Ukrainian].

Svitova Federacija Ukrajinsjkykh Zhinochykh Orghanizacij. Mizhnarodna orghanizacija. Retrieved from: http://wfuwo.org/ (accessed 20 October 2020) [in Ukrainian / English].

Open Ukraine Arseniy Yatsenyuk Foundation. Blaghodijnyj fond. Retrieved from: https://openukraine.org/en (accessed 20 October 2020) [in English].

Sorman Guy (2017) El poder blando ABC, zreferuvala Ghalyna Ghrabovsjka. Retrieved from: https:/ / zbruc.eu/node/ 69324 (accessed 20 October 2020) [in Ukrainian].

The soft power 30 (2019) by Portland USC Center on Public Diplomacy. Retrieved from: https://softpower30.com/ (accessed 16 October 2020) [in English].

\section{Анотаиія}

\section{Савон К. В. Вплив політики «м'якої сили» на імідж держави. - Стаття.}

У статті досліджено категорії «сила», «м'яка сила» та «жорстка сила». «М'яка сила» базується на культурному, ідеологічному та політичному складниках, тоді як «жорстка сила» заснована на військово-економічній могутності. Наведені різні визначення поняття «сили» у міжнародних відносинах. У різні історичні періоди теоретики та політичні діячі по-різному розуміли «силу» та інтерпретували iї. Зроблено висновок про взаємозалежність категорій «сили» та «влади».

Наведено класифікацію складників «м'якої сили» за Ін Фанєм і розробками Центру публічної дипломатії Університету Південної Каліфорнії - Індексу м'якої сили. Проаналізовано складники Рейтингу «м'якої сили» на основі досліджень американського політолога Дж. Ная. Перелічені 10 країн із найвищими показниками цього рейтингу у 2019 році. Франція, політика якої обійняла 1 сходинку у впливі «м'якої сили» на інші держави, була проаналізована з позиції успішних складників іії іміджу. Успішний вияв «м'якої сили» продемонстрували скандинавські та деякі азіатські держави.

Використовуючи різні методи просування своїх інтересів, спільним для багатьох держав із позитивним іміджем є створення національних Інститутів у різних державах світу, в яких вивчають мову та культуру держави. КНР та Японія нарощують свою силу через економічний складник, хоча ставлення до їхніх товарів у світі різне, однак товари з обох держав є популярними. Скандинавські держави закріплюють за собою статус найщасливіших держав, охоплюючи найвищі показники у міжнародних рейтингах, акцентуючи увагу на екологічній політиці та вручаючи Нобелівські премії. Однак масова культура залишається одним із головних інструментів «м'якої сили».

Важливе значення на міжнародній арені відіграють міжнародні організації та фонди, які висвітлюють національні інтереси держави. Так, діяльність Фонду «Відкрий Україну», Світова Федерація Українських Жіночих Організацій і Всесвітній конгрес українців, які функціонують в Україні та в діаспорі, підвищують авторитет України у світі. Зроблено висновок про можливості для України використання потенціалу «м'якої сили» у побудові та просуванні позитивного іміджу держави.

Ключові слова: імідж держави, Індекс м'якої сили, «жорстка сила», «м'яка сила».

\section{Summary}

Savon K. V. The influence of the "soft power" policy on the image of the state. - Article.

The article analyzes the categories of "power", "soft power" and "hard power". The "soft power" is based on the cultural, ideological and political components, while "hard power" is based on military and economic power. The different definitions of the "force" term in the international relations are provided. Philosophers and politicians have realized and interpreted "power" variously in different historical periods.

It is concluded that the categories of "force" and "power" are linked. The classifications of the components of the "soft power" are described according to Ying Fan and The Development of the Center on Public Diplomacy of the University of Southern California - Soft Power Index. The components of The Soft Power rating are analyzed, based on the research of the American political scientist J. Nay. 10 countries that have the highest position in this rating in 2019 are enumerated.

France, whose policy took the first place in the influence of the "soft power" on other countries, was analyzed from the side of the successful components of its image. The Scandinavian and some Asian countries have shown a successful manifestation of the "soft power". Using the different methods of promoting their interests, common factor for many countries with a positive image is creation of national institutes in different 
countries of the world, where they study the language and culture of the state. China and Japan are increasing their strength with help of the economic component. Despite the fact that attitude to goods in the world is different, goods from both countries are popular. The Scandinavian countries keep the status of the happiest countries, showing the highest indicators in the international rankings, focusing on the environmental policy and holding the Nobel Prize.

However, mass culture stands as one of the main tools of the "soft power". International organizations and foundations which cover the promotion the national interests of the state play an important role in the international community. The activities of the Open Ukraine Foundation, The World Federation of Ukrainian Women's Organizations and The Ukrainian World Congress which function in Ukraine and in the diaspora, increase Ukraine's prestige in the world. The conclusion is made about the possibilities for Ukraine to use the potential of the "soft power" in building and promoting a positive image of the state.

Key words: soft power index, country image, "hard power", "soft power". 